\title{
Antibacterial Activity of Eight Medicinal Plants against Multidrug Resistant Escherichia coli and Salmonella spp. isolated from Broiler Meat
}

\author{
Md. Rayhan Ali, Md. Omar Faruque, Md. Tarek Molla, Roksana Khanam, \\ Shahin Mahmud*, A.K.M. Mohiuddin*, \\ Department of Biotechnology and Genetic Engineering, Mawlana Bhashani Science and \\ Technology University, Tangail-1902, Bangladesh \\ *Corresponding authors: shahin018mbstu@gmail.comªkmmohiu@yahoo.com
}

How to cite this paper: Ali, M.R., Faruque, O., Molla, M.T., Khanam, R., Mahmud, S. and Mohiuddin, A.K.M. (2020).

Antibacterial Activity of Eight Medicinal Plants against Multidrug Resistant

Escherichia coli and Salmonella spp. isolated from Broiler Meat. Grassroots Journal of Natural Resources, 3(4): 28-48. Doi:

https://doi.org/10.33002/nr2581.6853.03043

Received: 24 September 2020

Reviewed: 12 October 2020

Provisionally Accepted: 17 October 2020

Revised: 31 October 2020

Finally Accepted: 10 November 2020

Published: 20 December 2020

Copyright $(92020$ by author(s)

This work is licensed under the Creative Commons Attribution International License (CC BY 4.0). http://creativecommons.org/licenses/by/4.0/

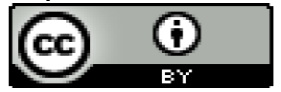

Open Access

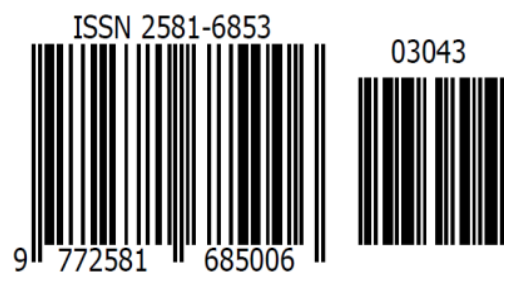

\begin{abstract}
The excess use of antimicrobial agents in the poultry industry is a significant reason for the gradual spread and increasing level of multidrug resistance bacteria. This article is based on a study in which the antibacterial activity of aqueous, methanolic, ethanolic and acetonic extracts of eight medicinal plants were evaluated by standard disc diffusion method against multidrug resistant Escherichia coli and Salmonella spp. isolated from broiler meat. The multidrug resistance was checked by commercially available antibiotics using standard disc diffusion method. The results have indicated that the ethanolic extract of Boerhaavia diffusa showed maximum zone of inhibition against Escherichia coli, while Asparagus racemosus showed maximum zone of inhibition against Salmonella spp. Other experimental plant extracts had showed moderate activity against these multidrug-resistant bacteria, which can also be considered as potential source of active beneficial phytochemicals. Proper management and application of these plant extracts may be a wonderful alternative of commercially available antibiotic to minimize the risk.
\end{abstract}

Keywords

Antibiotics; Broiler meat; Multidrug resistance; Salmonella spp.; Eschericia coli 


\section{Introduction}

Antibiotic resistance occurs when microorganisms can survive in the presence of an antibiotic that would normally inhibit their growth (Fadare et al., 2019). Different kinds of antibiotics are used in the poultry industry to increase feed conversion, growth promotion, and disease prevention to improve meat production. Promoting growth in poultry production, antibiotics can be widely used successfully as sub-therapeutic, prophylactic, and growth-promoting agents, for nutritive purposes, and to protect the health of birds by modifying the immune status of broiler chickens (Hassan et al., 2010; Emami et al., 2012; Lee et al., 2012; Chattopadhyay, 2014). This is mainly used to control the gastrointestinal infections and microbiota modification in the intestine of poultry birds (Torok et al., 2011; Singh et al., 2013). The mechanism remains unclear, but antibiotics are likely to act by remodeling microbial diversity and relative abundance in the intestine to provide an optimal microbiota for growth (Dibner and Richards, 2005). However, scientific evidence suggests that the massive use of these compounds has led to the increasing problem of antibiotic resistance and the presence of antibiotics residues in feed and environment compromises human and animal health (Furtula et al., 2010; Forgetta et al., 2012; Carvalho and Santos, 2016; Ronquillo and Hernandez, 2017). Due to the lack of knowledge, the condition and dosing rate of antibiotic in poultry farming is not proper and that may be the considerable reason for antibiotic resistance of different bacterial species. Indiscriminate use of antibiotics results into noticeable residues in meat, milk, cheese, butter, and other livestock products that may cause serious problems to consumers (Lee et al, 2000).

Currently, it is estimated that antibiotic resistance causes approximately 700,000 people to die each year. By the year 2050, this number of deaths is predicted to reach 10 million annually (de Kraker, Stewardson and Harbarth, 2016). It represents one of the most alarming threats to global health, and new anti-infective agents are needed to overcome this antibiotic resistance (Thabit, Crandon and Nicolau, 2015). Hence, it is essential to find effective alternative agents to control infectious diseases and limit the spread of antibiotic-resistant bacteria. Further, new mechanisms of action of these novel anti-infective agents are needed (Schroeder, Brooks and Brooks, 2017). It is believed that plants may contain different bioactive compounds and that would be a good source of novel anti-infective agents (Rossiter, Fletcher and Wuest, 2017). In traditional medicinal practices against infections, plants have been used to inhibit the growth and virulence of various microbes (Ahmad and Beg, 2001; Kumar et al, 2012; Bashir, Erum and Kausar, 2012, Cioch et al, 2017). A diverse array of chemical compounds known as secondary metabolites are synthesized by plants to communicate with other organisms (Harborne, Baxter and Webster, 1994). In addition, these secondary metabolites are advantageous for anti-infective agents or bioactive drug development and harboring the potential for synergy with other secondary metabolites as a part of the plant's multicomponent defense system (Harvey, Edrada-Ebel and Quinn, 2015). There is no bacteriostatic or bactericidal medicine available in the market derived from plant secondary metabolites. Alternative anti-infective mechanisms of action can open new avenues in drug development to combat antibiotic resistance where natural products may serve as a critical reservoir to overcome resistance mechanisms (Schroeder, Brooks and Brooks, 2017; Wright, 2017). As there is a growing demand for alternative plant-derived compounds that have fewer side effects than synthetic compounds, and whose effectiveness can be improved by modern pharmacological methods (Wilasrusmee et al., 2002). Based on observations of traditional use for the treatment of infectious diseases and literature searches on their reported known activities, eight medicinal plants were selected. These species are present in abundant populations in the collection regions (Tangail 
district, Bangladesh) and none are listed as threatened or endangered. The objective of this study is to evaluate the antimicrobial activity of different extracts of eight medicinal plants against the growth of E. coli and Salmonella spp. The essential criteria for the selection of each plant species are explained below.

Coccinia grandis (Leaf): This plant belongs to the family of Cucurbitaceae. It is found in tropical Asia (India, Pakistan, Bangladesh, Sri Lanka, Indonesia, Malaysia, the Philippines, and Thailand), and Africa (Sakharkar and Chauhan, 2017). Various kinds of plant parts are valuable medicine and various preparations have been mentioned in the indigenous system of medicine for various skin diseases, bronchial phlegm and bronchitis. Traditionally, in Unani and herbal medicine used in treating worm, psoriasis, smallpox, scabies and other itchy skin eruptions and ulcers (Miller et al., 2000; Quinlan, Quinlan, and Nolan, 2002). The effective leaves of the plant possess anti-diabetic, antipyretic, anti-inflammatory, analgesic, and antimicrobial properties. It is also useful to induce perspiration in fever and cures sores in the tongue (Farrukh et al., 2008). Phytochemical screening of $C$. grandis reported the presence of saponins, cardenolides, flavonoids, and polyphenols may be attributed to antibacterial activity (Sivaraj et al., 2011).

Acacia macrorrhizos (Stem): This is an important medicinal plant from the Araceace family in the tropical and subtropical regions of Asia, Sri Lanka, India, Bangladesh, China, South Africa, and mainly cultivated in India and Bangladesh (Mandal, Misra and Singh, 2010). It has various pharmacological properties like thrombolytic, antifungal, antimicrobial, anticancer, analgesic, hepatoprotective, hepatorenal. Its antioxidant property is also recommended in Ayurvedic text for prevention and treatment of inflammation of abdomen and spleen (Banik et al., 2014). The juice of leaves is used as digestive, anthelmintic, laxative, diuretic, and astringent (Srivastava et al., 2012). This plant contains flavonoids, oxalic acid, cyanogenic glycosides, alocasin, cholesterol, amino acids, gallic acid, maleic acid, ascorbic acid, succinic acid, glucose, fructose, sucrose and beta lectins (Hasan and Sultana, 2018).

Jatropha curcas (Leaf): It was originated from Mexico with spread to Asia and Africa by Portuguese traders as a hedge plant. It belongs to the family of Euphorbiaceae (Rampadarath, Puchooa and Jeewon, 2016). Parts of J. curcas have been used in traditional medicine and in veterinary care (Suhaili et al., 2011). J. curcas has shown characteristics of potent cytotoxic, antitumor, antimicrobial, and anti-fungal agent (Rahman et al., 2014), it is also used as anticoagulant (Suhaili et al., 2011). The extract of seeds and leaves of J. curcas have shown molluscidal and insecticidal properties (Rampadarath, Puchooa and Jeewon, 2016). It has also been used as antidote, remedy, medicine and a potential source of herbal drugs in dental complaints and against constipation. The milky sap is used for the treatment of dermatomucosal diseases (Dada, Ekundayo and Makanjuola, 2014). Moreover, Jatropha curcas (leaf) is commonly used for aching patients with colds or fever. A study has shown that it contains an alkaloid known as jatrophine, which is believed to have anti-cancerous properties. The latex of the plant can be used as a remedy for alopecia, anasarca, burns, dropsy, eczema, inflammation, paralysis and yellow fever (Morton 1980; Dada, Ekundayo and Makanjuola, 2014).

Leucas lavandulifolia (Leaf): Leucas lavandulifolia belongs to the family of Labiatae and is a wellknown ethnomedicinal plant. It has been used in Bangladesh for traditional medicine from the time memorial and usually used in cough, cold, fever, loss of appetite, skin disease, headache, snakebite and scorpion sting (Makhija et al., 2011). It also shows antibacterial activity against multidrug- 
resistant bacteria such as E. coli. Other properties, i.e., hepatoprotective, hypoglycemic, antipyretic, antidiarrheal, antitussive, wound healing and psychopharmacological, antimicrobial activities of the plant have been reported by in vivo study conducted by Murugan, Mishra and Paul (2018).

Boerhaavia diffusa (Leaf): Boerhaavia diffusa belongs to the family of Nyctaginaceae. It is used as an Ayurvedic medicine in India and Unani medicine in Arab countries for the treatment of diabetes, jaundice, stress, dyspepsia, inflammation, abdominal pain, enlargement of the spleen and congestive heart failure (Akhter et al., 2013). It is an herbaceous plant, cultivated in fields spreading vine widely distributed in tropical and subtropical regions (Sahu et al., 2008). For medicinal purposes, the whole plant parts such as roots, leaves, flowers, seeds, etc. are used. Apart from above, Boerhaavia diffusa also possesses marked antimicrobial properties viz. antibacterial properties and antifungal properties (Olukoya, Idika and Odugbemi, 1993; Agrawal et al., 2004; Aladesanmi et al., 2007). It has also been reported to be useful in the treatment of elephantiasis, night blindness, corneal ulcers, and nephritic syndrome (Umamaheswari, Nuni and Shreevidya, 2010). All the properties have made this plant very important in the treatment of human and plant diseases.

Catharanthus roseus (Leaf): Catharanthus roseus belongs to the family of Apocynaceae, which is an erector procumbent herb or undershrub containing latex. Different studies have shown that Catharanthus roseus contains more than seventy different types of therapeutic agents or alkaloids that can be used in treating various diseases including lung cancer, breast cancer, uterine cancer, melanomas and Nonhodgkin's lymphoma (Kainsa, Kumar and Rani, 2012). It is reported that the plants have antibacterial potential in crude extracts of different parts (viz., leaves, stem, root, and flower) (Muhammad et al., 2009). It possesses known antibacterial, antimicrobial, antifungal, and diabetic, anticancer and antiviral activities against numerous cell types (Raza et al., 2009).

Hemidesmus indicus (Root): Hemidesmus indicus (root) is pharmacologically important plant belonging to the Asclepiadaceae family (Kavitha et al., 2010). A study showed that $H$. indicus root extract inhibited Salmonella typhimurium induced pathogenesis nonspecifically, by reducing hydrophobicity of bacterial cell surface and perhaps also by mimicking host cell receptors and thereby blocking its attachment to host cell (Das and Devaraj, 2006). The H. indicus root powder or its water extract can increase its antidiarrheal efficacy if incorporated in oral rehydrating salt solution (Evans, Rajasekharan and Subramoniam, 2004.). The plant root is said to be tonic, as its root decoction helps in skin diseases, elephantiasis, syphilis, blood purification, loss of appetite and for kidney and urinary disorders. Other biological activities i.e., antidiabetic, antioxidant, hepatoprotective, antithrombotic, anti-ulcerogenic, anti-inflammatory, immunomodulatory, etc. have been reported from Hemidesmus indicus root extracts (Ratha et al., 2012).

Asparagus racemosus (Root): This plant belongs to the family of Aspragaceae. It is an important medicinal plant traditionally used as anthelmintic, antiseptic, antidiarrheal, and antidysentery and anti-cancer agent (Kunwar et al., 2009). This plant is recommended in Ayurvedic medicine for prevention and treatment for inflammation, nervous disorder, liver diseases, infectious diseases, gastric ulcers, dyspepsia, and as a galactagogue (Sinha and Biswas, 2011). The methanolic root extract of $A$. racemosus is beneficial to in vitro antibacterial activity against various common pathogens (Mandal et al., 2000). The root of Asparagus racemosus has shown considerable activity 
against nervous disorders, dyspepsia, diarrhea, dysentery, inflammations, neuropathy, hyperdipsia, antioxidant, antitussive, and certain infectious diseases (Goyal, Singh and Lal, 2003).

\section{Materials and Methods}

\section{Study area}

This study was conducted in 5 regions of Sherpur district, Bangladesh (figure 1) during the period from March 2017 to December 2017. In this area, poultry rearing has become very popular, though the environment is unhygienic. It was an important reason for evaluating the antibiogram pattern of isolates where all the samples were randomly selected and collected from poultry farms or local retail markets.

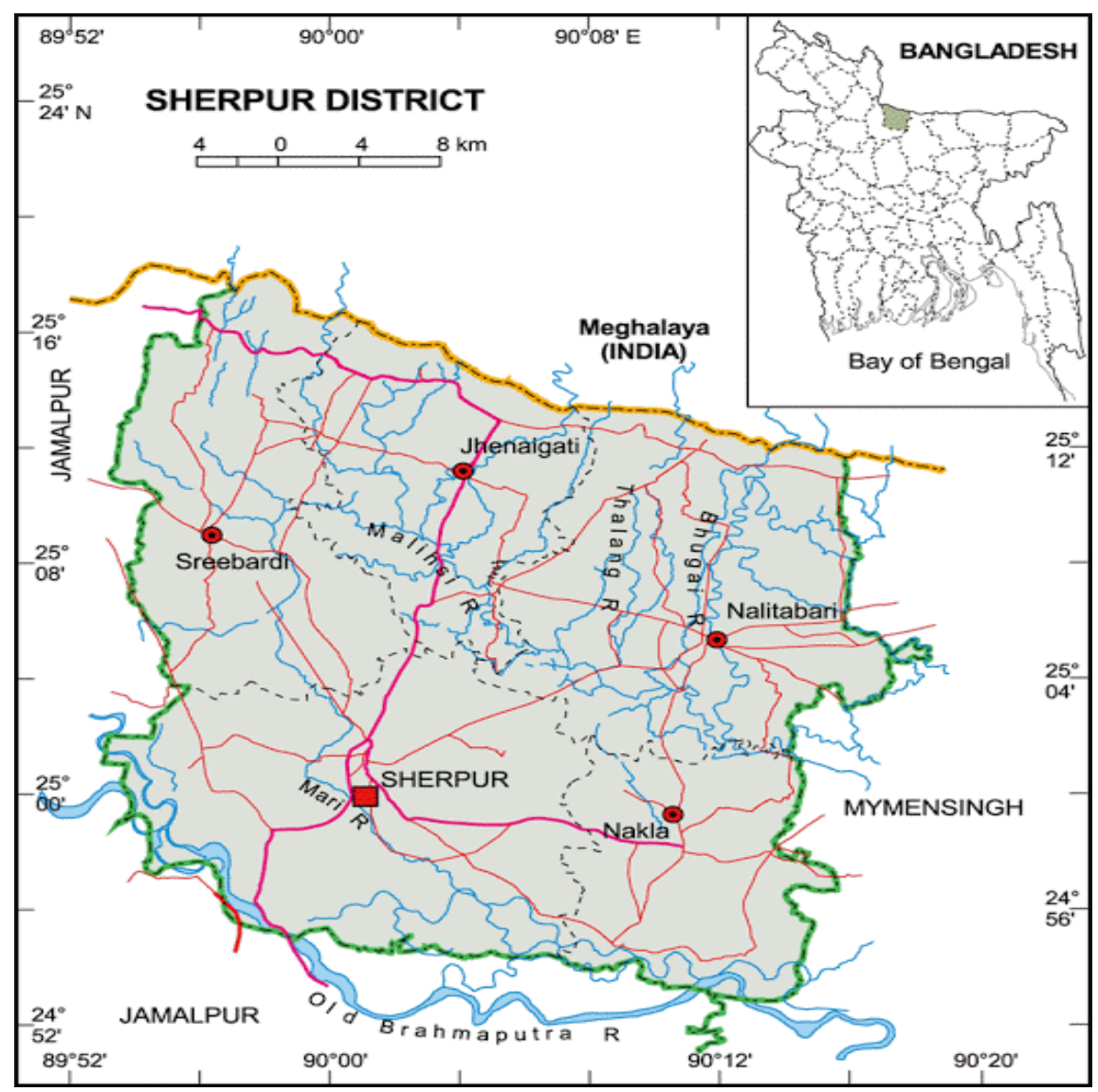

Figure 1: Geographical location of study area

\section{Collection and transportation of samples}

A total of 50 dressed broiler carcasses were collected. From among them 25 were collected during winter and 25 were collected during the summer season. They were immediately brought to Microbiology Laboratory of the Department of Biotechnology and Genetic Engineering, Mawlana Bhashani Science and Technology University, Tangail through maintaining cool chain using icebox. 


\section{Preparation of samples for bacteriological studies}

Each of the raw meat samples (thigh muscle, breast muscle, and drumstick) was macerated in a mechanical blender using a sterile diluent as per the recommendation of the International Organization for Standardization (Hossain et al., 2015). Ten grams of the thigh meat sample was taken aseptically with sterile forceps and transferred into sterile containers containing $90 \mathrm{ml}$ of $0.1 \%$ peptone water. A homogenized suspension was made in a sterile blender. Thus, 1:10 dilution of the samples was obtained.

\section{Isolation of associated bacteria}

The primary culture was performed in nutrient agar and nutrient broth media. For sub-culturing, suspected bacteria were inoculated separately into different bacteriological media under the aseptic condition and incubated at $37^{\circ} \mathrm{C}$ for 18 hours. Pure cultures were achieved by further sub-culturing on selective agar.

\section{Identification of associated bacteria}

Cultural, morphological, and biochemical characteristics were studied to identify the bacterial flora. The cultural characteristics or colonial morphology of the bacterial grown on MacConkey agar, SS agar, the eosin methylene blue (EMB) and xylose lysine deoxycholate (XLD) agar were recorded. Gram staining was performed to study the morphology and staining characteristics of the bacteria. Biochemical tests, such as sugar fermentation, methyl red (MR), Voges-Proskauer (VP), and indole tests, were performed to identify the bacteria tentatively. Isolates were confirmed by microscopic, cultural and standard biochemical tests (KIA, motility, catalase, coagulase, oxidase, urease, citrate utilization, indole, gelatin hydrolysis, MR-VP, TSI test) according to Bergey's Manual of Determinative Bacteriology (9th Edition, 1994) for further analysis (Bullock and Aslanzadeh, 2013).

\section{Collection and preparation of plant extract}

The leaves, stems, and roots of the desired plants were collected from the university campus of Mawlana Bhashani Science and Technology University. All the plant parts were washed with clean water to remove dirt, dried in air and pulverized using mortar and pestle. The plant extracts of different concentrations were made in different solvents using a vacuum evaporator machine by following standard method (Zrostlikova et al., 2002).

\section{Antibiotic Susceptibility Testing}

The antibiotic susceptibility of the isolates i.e., Salmonella and E. coli was determined using the standard disc-diffusion method (Adesiyun et al., 2007). The antibiotic discs (Oxoid®, UK) used in this study were: ampicillin $(10 \mu \mathrm{g})$, azithromycin $(15 \mu \mathrm{g})$, amoxicillin $(10 \mu \mathrm{g})$, bacitracin $(10 \mu \mathrm{g})$, ciprofloxacin $(5 \mu \mathrm{g})$, chloramphenicol $(30 \mu \mathrm{g})$, cefaclor $(30 \mu \mathrm{g})$, erythromycin $(15 \mu \mathrm{g})$, gentamicin $(10 \mu \mathrm{g})$, kanamycin $(30 \mu \mathrm{g})$, neomycin $(30 \mu \mathrm{g})$, nalidixic acid $(30 \mu \mathrm{g})$, norfloxacin $(10 \mu \mathrm{g})$, penicillin $\mathrm{G},(10$ units $)$, streptomycin $(10 \mu \mathrm{g})$, sulphomethoxazole tetracycline $(30 \mu \mathrm{g})$, vancomycin (30 $\mu \mathrm{g})$. 


\section{Evaluation of the antibacterial activity of plant extract by disk diffusion method}

The disk of filter paper was made and socked in different concentrations of plant extract and dried for the use of susceptibility test of Salmonella and E. coli. The disks soaked with water, ethanol, methanol and acetone were used as a control disk (Tambekar et al., 2009).

\section{Results and Discussion}

\section{Biochemical Test for Bacterial Analysis}

Two kinds of bacteria (E. coli, Salmonella spp.) were isolated by observing distinct morphological characteristics on selective media and further confirmed with standard biochemical tests (Table 1). The E. coli isolates were observed in EMB agar as smooth, circular, greenish-black color colonies with metallic sheen whereas pink color colonies were observed in Mac-Conkey agar (Schroeder, Brooks and Brooks, 2017; Wright, 2017). The Salmonella spp. were observed as smooth, circular, black centered colonies in XLD agar and SS agar. In Gram's staining, the morphology of both bacteria exhibited Gram-negative, short rod arranged in single or paired (Wilasrusmee et al., 2002; Schroeder, Brooks and Brooks, 2017; Sakharkar and Chauhan, 2017).

Table 1: Biochemical test for bacterial analysis

\begin{tabular}{|c|c|c|c|c|c|c|c|c|c|c|c|c|c|c|c|c|c|}
\hline \multirow[b]{3}{*}{ 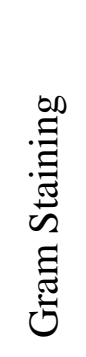 } & \multicolumn{16}{|c|}{ Biochemical reaction } & \multirow{3}{*}{$\begin{array}{l}\text { Presumptive } \\
\text { Bacteria }\end{array}$} \\
\hline & \multirow[b]{2}{*}{ 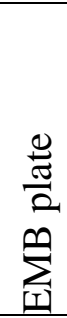 } & \multicolumn{3}{|c|}{ KIA } & \multicolumn{3}{|c|}{ MIU } & \multirow[b]{2}{*}{ 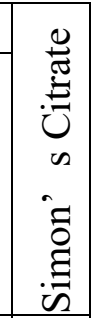 } & \multirow[b]{2}{*}{ 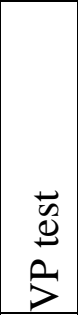 } & \multirow[b]{2}{*}{$\begin{array}{c}0 \\
\frac{\mathscr{J}}{\tilde{J}} \\
\cdot \frac{\pi}{x} \\
0\end{array}$} & \multirow[b]{2}{*}{ 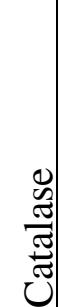 } & \multirow[b]{2}{*}{ 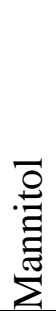 } & \multirow[b]{2}{*}{ 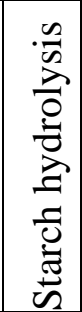 } & \multirow[b]{2}{*}{ 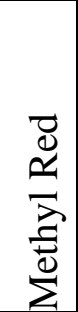 } & \multirow[b]{2}{*}{$\begin{array}{l}\ddot{\mathscr{D}} \\
\stackrel{0}{0} \\
\stackrel{0}{0}\end{array}$} & \multirow[b]{2}{*}{ 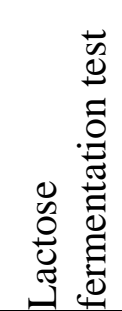 } & \\
\hline & & 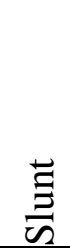 & $\stackrel{\overrightarrow{0}}{\oplus}$ & $\tilde{\Xi}$ & 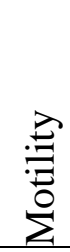 & $\begin{array}{l}\frac{0}{0} \\
\frac{0}{0} \\
\end{array}$ & 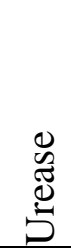 & & & & & & & & & & \\
\hline$-\mathrm{Ve}$ & + & $\mathrm{A}$ & $\mathrm{A}$ & + & + & + & + & - & - & - & + & $\mathrm{A}$ & - & + & $\begin{array}{l}A \\
G\end{array}$ & + & E. coli \\
\hline$-\mathrm{Ve}$ & - & $\mathrm{K}$ & $\mathrm{A}$ & $\mathrm{G}$ & + & - & + & + & - & - & - & A & - & + & - & - & $\begin{array}{l}\text { Salmonella } \\
\text { spp. }\end{array}$ \\
\hline
\end{tabular}

\section{Bacterial load of Broiler Meat during Winter and Summer Season}

Bangladesh has six seasons: summer (Grisma), rainy (Barsa), autumn (Sarat), late autumn (Hemonta), winter (Shhit), spring (Basanta). Each season stays normally for two months. However, three seasons, pre-monsoon, rainy monsoon or summer and winter season, are prominently recognized. Winter comes after the late autumn, and, generally, it starts in October and lasts up to February. Winter temperature ranges from $3^{\circ} \mathrm{C}$ or $6^{\circ} \mathrm{C}$ to $10^{\circ} \mathrm{C}$. On the other hand, summer season stays from March to June at a temperature range between $25^{\circ} \mathrm{C}$ to $35^{\circ} \mathrm{C}$. Total Viable Count (TVC), Total Coliform Count (TCC), Total E. coli Count (TEC), Total Salmonella spp. Count (TSC) of samples were conducted among six places of Nalitabari township during winter and summer season (Figure: 2). Microbial count is slightly higher in all the samples compared to the standard. The 
favorable environmental conditions of summer and unfavorable acclimatization of winter are an important factor for this high microbial load in summer. Shigella was not found in any samples that were collected in either summer or winter season.

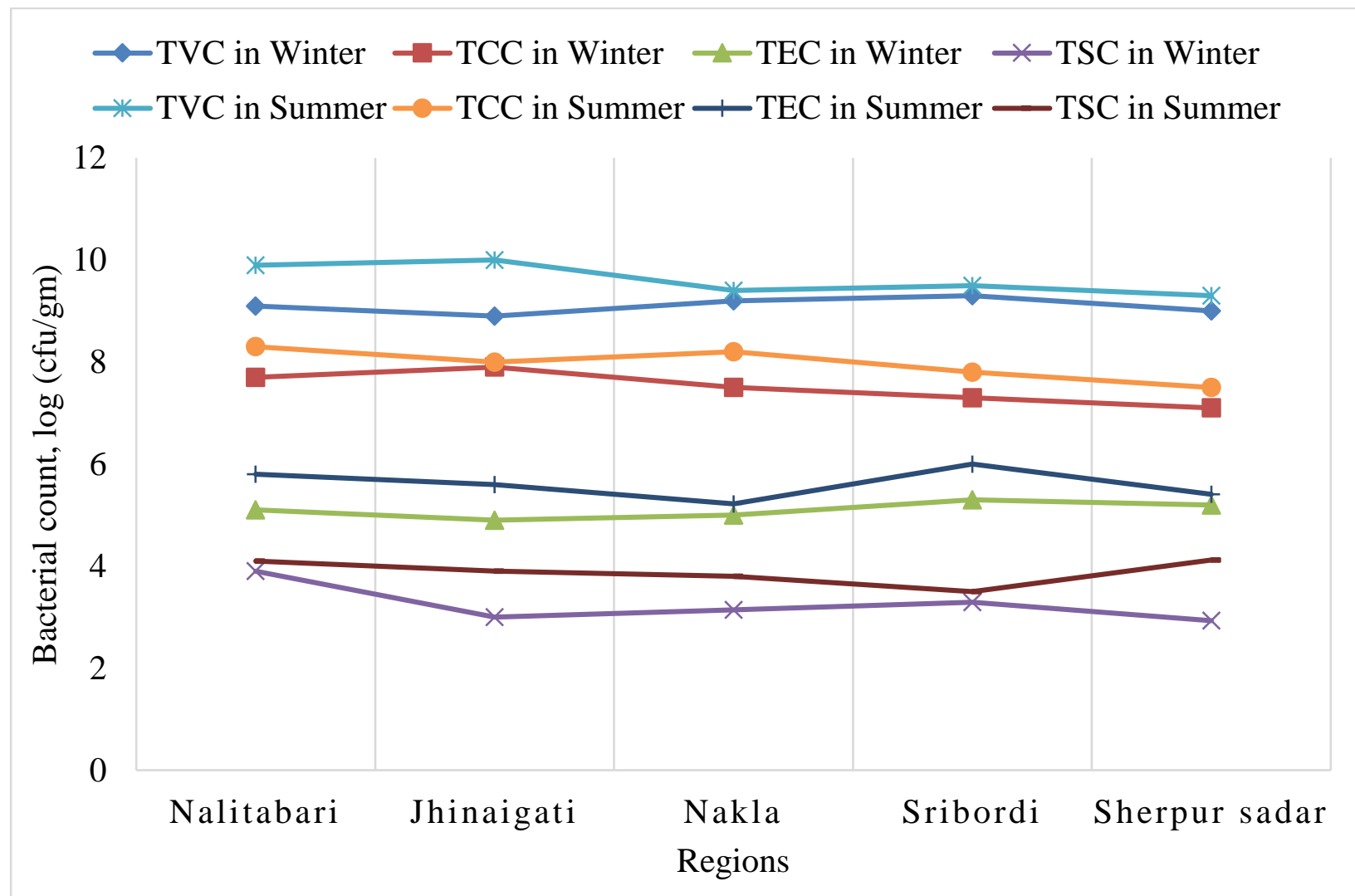

Figure 2: Presence of microorganism in boiler meat during winter and summer sessions

\section{Antibiotic Resistance Pattern}

The possession of such factors by the $E$. coli isolates signifies the fact that the organisms might have gained the resistance property due to the indiscriminate use of antibiotics. The occurrence of isolated bacteria should be considered as hazardous to health and advocate the preventing risk factors. Resistance against commercially available and commonly used antibiotics has been observed in bacteria present in broiler since the introduction of these antimicrobial agents in poultry discriminately. The rise in antibiotic resistance has been reported in the past two decades in many countries including Bangladesh (Saha et al., 2005). Antibiotic susceptibility test was done in randomly selected 30 isolates (15 of E. coli and 15 of Salmonella spp.). The response of commercially available antibiotics against bacteria was categorized into three groups, i.e., sensitive, intermediate, and resistant. In this study, E. coli showed high resistance to Amoxicillin (93.33\%), Ampicillin (86.67\%), Chloramphenicol (80\%), Penicillin (80\%), 60\% resistance to Streptomycin and Erythromycin, and $53.33 \%$ resistance to Neomycin. 


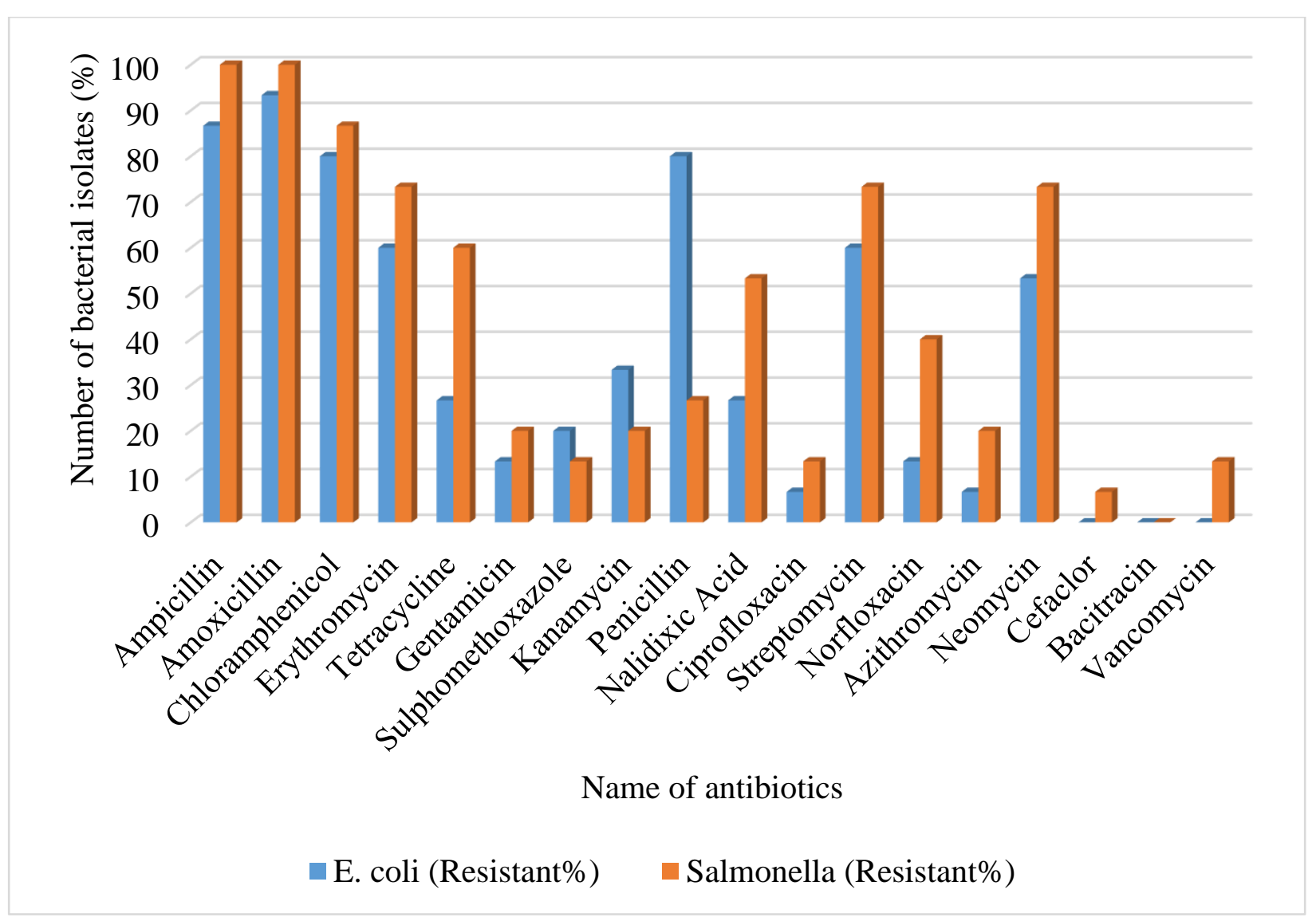

Figure 3: Antibiogram profiles of E. coli and Salmonella spp.

E. coli has shown high sensitivity to Bacitracin (93.33\%), Vancomycin, (86.67\%), Cefaclor (80\%), Ciprofloxacin (80\%), Gentamicin (73.33) and Azithromycin. (53.33\%) (figure 3). E. coli was moderately sensitive to Tetracycline $(53.33 \%)$ and Norfloxacin $(60 \%)$. The results strengthen the earlier observation of other studies (Perry and Metzger, 1980; Behl and Srivastava, 2002; Schroeder, Brooks and Brooks, 2017). The resistance of E. coli was observed against Ampicillin, Amoxicillin, Chloramphenicol, Penicillin, Erythromycin and Streptomycin (Schroeder, Brooks and Brooks, 2017). Earlier observations of studies conform to the fact that the E. coli isolated from broiler were sensitive to Azithromycin, Ciprofloxacin, Norfloxacin, and Gentamicin and resistant to Amoxicillin and Erythromycin. The possessions of such factors by the E. coli isolates signify the fact that the organisms might have gained the resistance property due to the unsystematic use of antibiotics (Chetri et al., 2020).

Salmonella spp. were 100\% resistant to antibiotics Ampicillin and Amoxicillin, 60\% resistant to Tetracycline and $53.33 \%$ resistant to Nalidixic Acid (figure 3), but they were highly sensitive to Chloramphenicol (86.67\%), Bacitracin (80\%), Erythromycin (73.33\%), Gentamicin (73.3\%), Ciprofloxacin (73.3\%) and Vancomycin (73\%). Previous studies also revealed that Salmonella spp. were sensitive to Ciprofloxacin, Gentamicin, and Azithromycin (Manjunath, Prakash and Vamseedhar Annam, 2011; Ansari et al., 2014) and resistant to Erythromycin and Amoxicillin (Nesa, Khan and Alam, 2011; Mulatu, Beyene and Zeynudin, 2014). Potential drug-resistant pathogens in normal broilers may be a serious public health concern. It was revealed that Salmonella spp. were sensitive to Bacteriocin, Vancomycin, Ciprofloxacin, Gentamicin, and 
Azithromycin (Mandal et al., 2010; Schroeder, Brooks and Brooks, 2017) and resistant to Chloramphenicol, Streptomycin, Neomycin and Erythromycin (Schroeder, Brooks and Brooks, 2017).

Evaluation of Antibacterial Activity of Eight Medicinal Plants against Multidrug Resistant E. coli and Salmonella spp.

Extract of eight different plants was used for antibacterial study against two different isolates such as E. coli and Salmonella spp. Ten E. coli and ten Salmonella spp. isolates were selected on the basis of antibiogram study, where they were resistant to more than one commercially used antibiotics (E. coli was higher resistance to Amoxicillin, Ampicillin, Chloramphenicol, Penicillin, when Salmonella spp. were maximum resistant to antibiotics Ampicillin and Amoxicillin, Chloramphenicol and Erythromycin). Four solvents such as double distilled water, methanol, ethanol and acetone were used for the preparation of plant extract. Commercially available Ciprofloxacin antibiotic was used as positive control.

Aqueous Plants Extracts against E. coli and Salmonella spp.

Aqueous extract of six plants including C. grandis, A. macrorrhizos, L. lavandulifolia, C. roseus, $H$. indicus and $A$. racemosus did not exhibit any activity at any concentration against $E$. coli. $J$. curcas exhibited zone of inhibition ( 9 and $8 \mathrm{~mm}$ ) at two higher concentrations (i.e., 100 and 50 $\mathrm{mg} / \mathrm{ml})$ and $B$. diffusa has showed zone of inhibition $(11,10,8$ and $7 \mathrm{~mm})$ at four concentrations (i.e., $100,50,25,12.5 \mathrm{mg} / \mathrm{ml})$ where both plants did not express any activity at the lowest $(6.25$ $\mathrm{mg} / \mathrm{ml}$ ) concentration (Figure 4).

Aqueous extract of C. grandis, A. macrorrhizos, L. lavandulifolia, C. roseus, H. indicus and A. racemosus did not exhibit any zone of inhibition against Salmonella spp. J. curcas exhibited a zone of inhibition $(8 \mathrm{~mm})$ at only $100 \mathrm{mg} / \mathrm{ml}$ concentration. B. diffusa has shown a zone of inhibition $(10,9,7 \mathrm{~mm})$ at four concentrations (i.e., $100,50,25,12.5 \mathrm{mg} / \mathrm{ml})$.

Aqueous extract $C$. grandis and $J$. curcas $(100 \mathrm{mg} / \mathrm{ml})$ did not show any activity against $E$. coli but $J$. curcas $(100 \mathrm{mg} / \mathrm{ml})$ showed activity against Salmonella $(11.7 \mathrm{~mm})$ as demonstrated by a previous study (Suhaili et al., 2011). Aqueous extract of A. macrorrhizos did not show any activity against Salmonella but has showed activity against E. coli (Farrukh et al., 2008). Aqueous extract of $B$. diffusa leaves showed higher activity against Gram-negative bacteria and moderate antibacterial activity against E. coli and Salmonella (Umamaheswari, Nuni and Shreevidya, 2010).

\section{Antibacterial Activity of Methanol Extracts against E. coli and Salmonella spp.}

Methanolic extract of eight plants exhibited a favorable result against E. coli. A. racemosus exhibited maximum activity $(18,16,15,12$ and $10 \mathrm{~mm})$ against Salmonella in all experimental concentrations $(100,50,25,12.5,6.25 \mathrm{mg} / \mathrm{ml})$. A. macrorrhizos and $J$. curcas exhibited $14 \mathrm{~mm}$ zone and $B$. diffusa and $C$. roseus exhibited $17 \mathrm{~mm}$ zone of inhibition at the highest concentration $(100 \mathrm{mg} / \mathrm{ml})$ where all of these four plants expressed $7 \mathrm{~mm}$ zone of inhibition at a lowest concentration $(6.25 \mathrm{mg} / \mathrm{ml})$. C. grandis $(10 \mathrm{~mm})$, L. lavandulifolia $(13 \mathrm{~mm})$ and $H$. indicus $(11$ $\mathrm{mm}$ ) expressed a moderate activity at highest concentration against $E$. coli. The last two of these plants did not express any activity at the lowest concentration. 


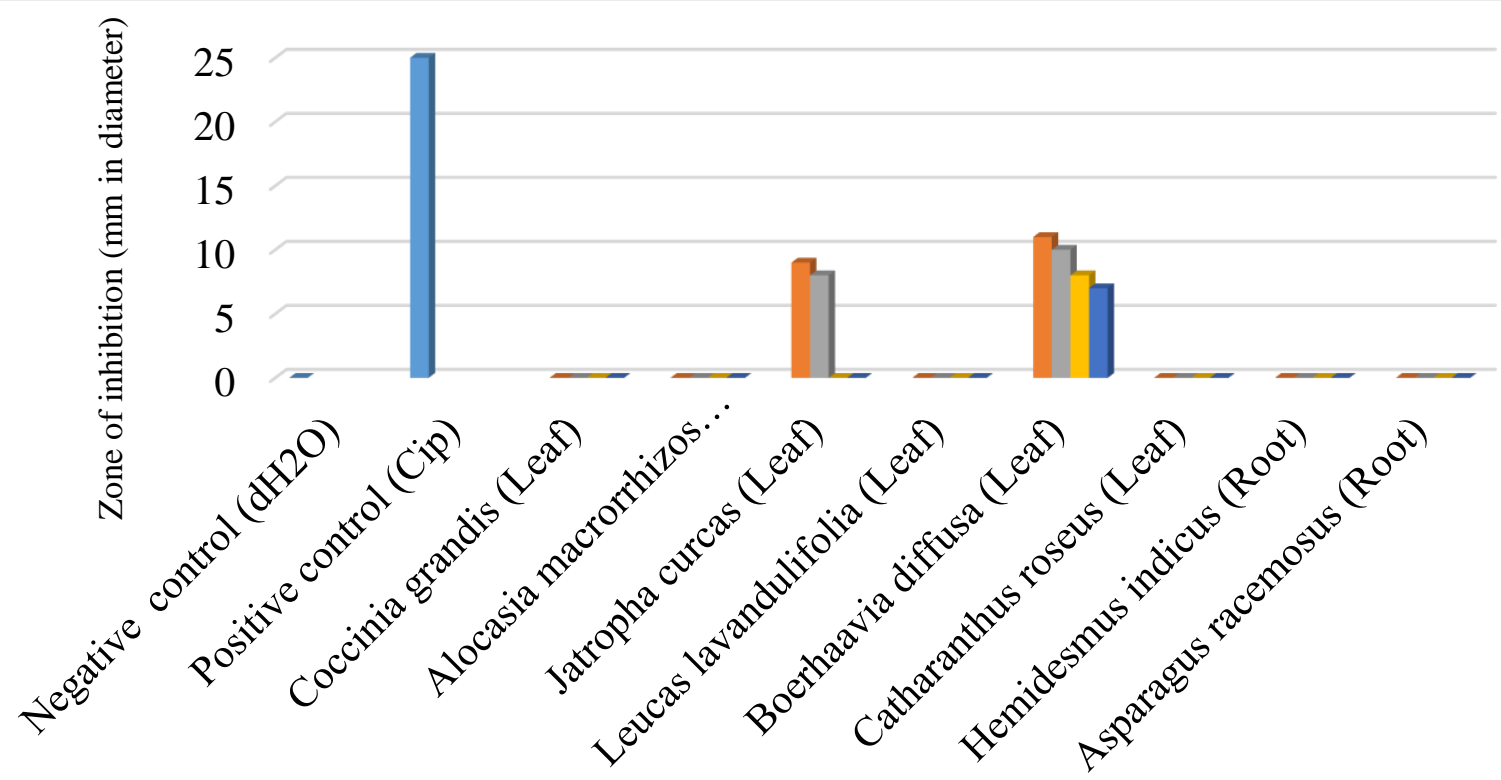

Name of the plants

Control $\square 100 \mathrm{mg} / \mathrm{ml} \quad \square 0 \mathrm{mg} / \mathrm{ml} \quad 25 \mathrm{mg} / \mathrm{ml} \quad \square 12.5 \mathrm{mg} / \mathrm{ml}$

Figure 4: Antibacterial activity of aqueous plants extracts against $E$. coli [Cip = Ciprofloxacin]

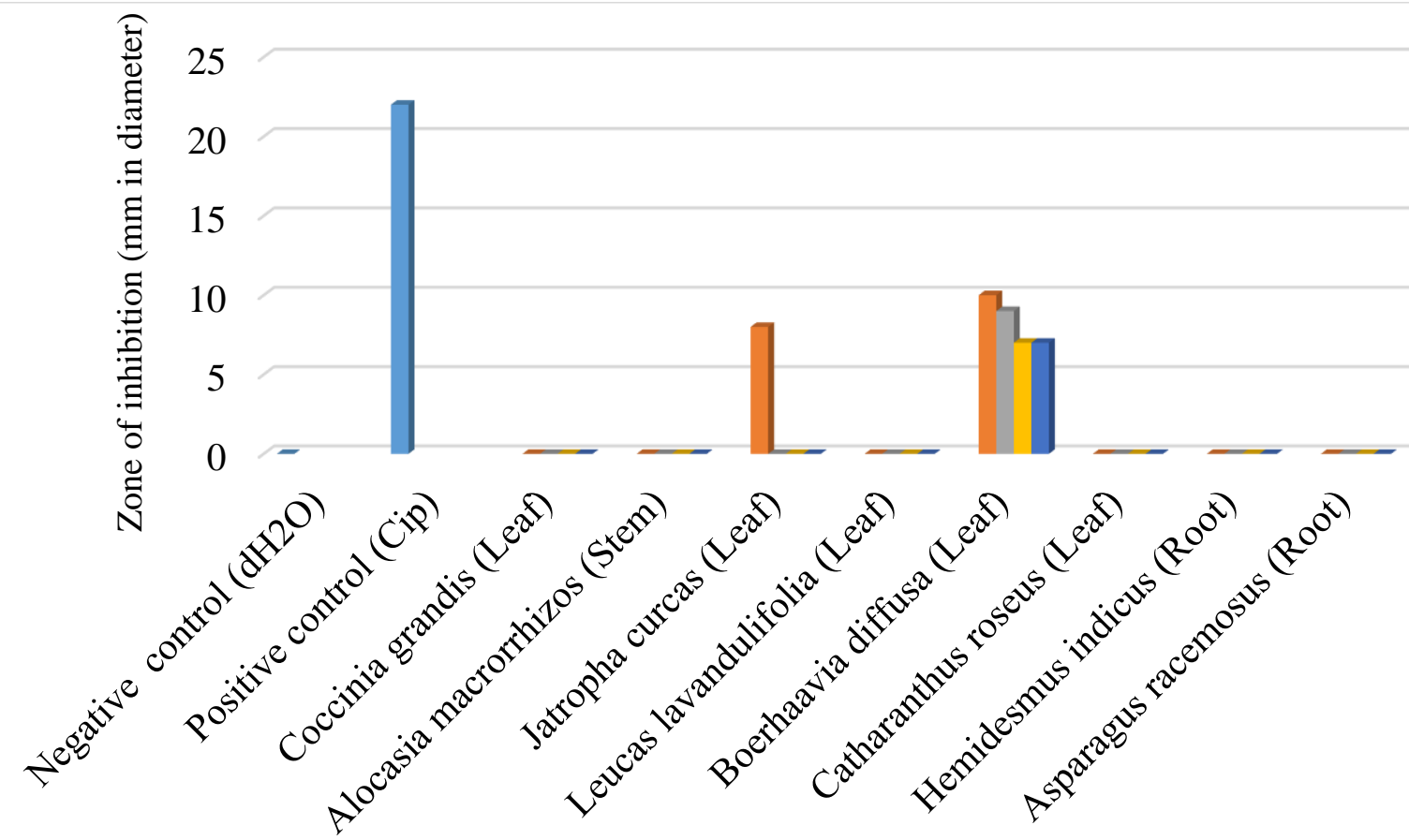

Name of the plants

$$
\text { Control } \square 100 \mathrm{mg} / \mathrm{ml} \quad \square 50 \mathrm{mg} / \mathrm{ml} \quad \square 25 \mathrm{mg} / \mathrm{ml} \quad \square 12.5 \mathrm{mg} / \mathrm{ml}
$$

Figure 5: Antibacterial activity of aqueous plants extracts against Salmonella spp. [Cip= Ciprofloxacin] 


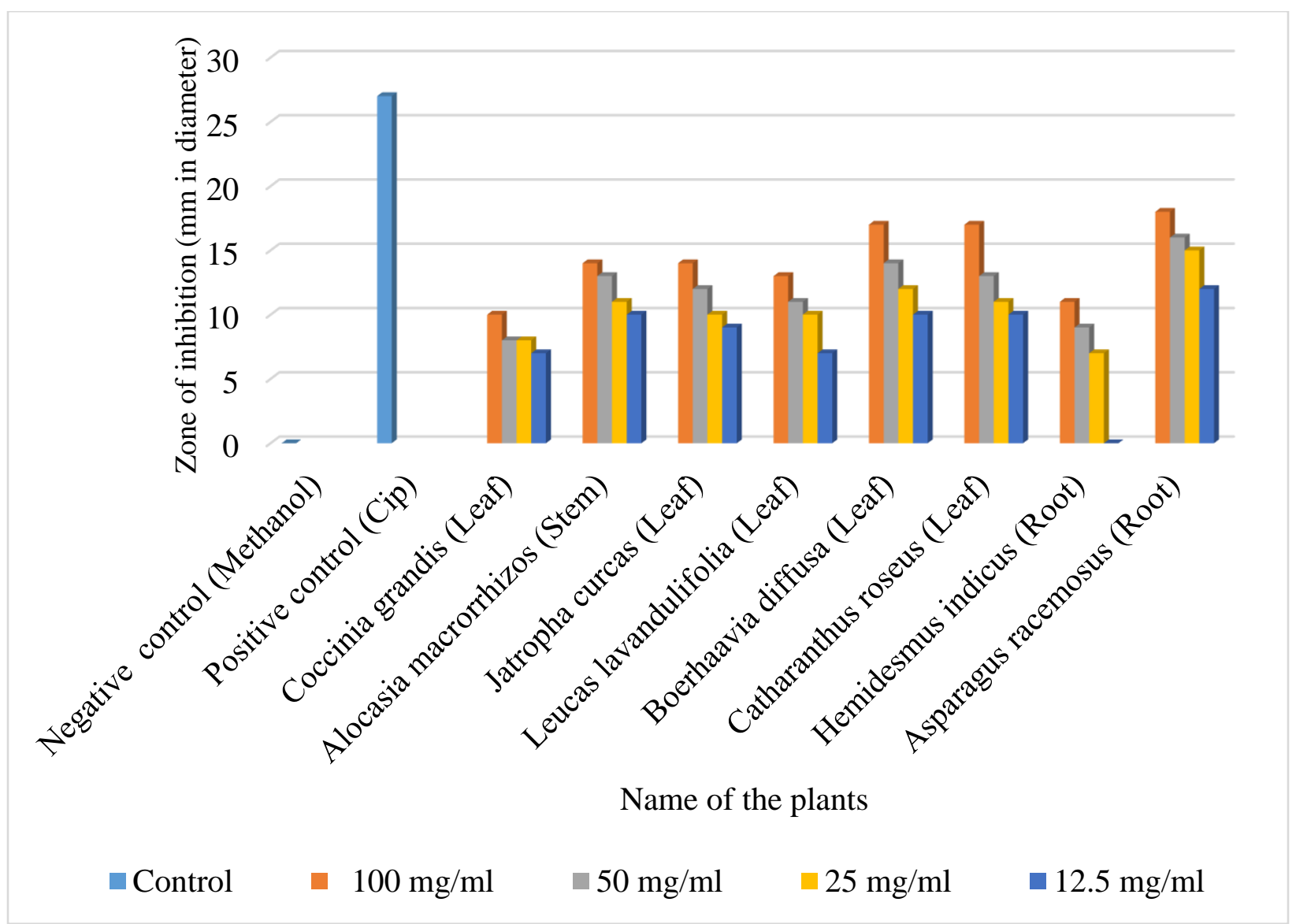

Figure 6: Antibacterial activity of methanol extracts against E. coli [Cip = Ciprofloxacin]

The antibacterial activity of $A$. racemosus methanolic extract was highest among these eight plants extract against Salmonella at five experimental concentrations. The plant extract of $C$. grandis and L. lavandulifolia did not have any antibacterial activity against Salmonella in any concentration. The activity of A. macrorrhizos $(10 \mathrm{~mm})$, J. curcas $(12 \mathrm{~mm}), B$. diffusa $(14 \mathrm{~mm}), C$. roseus $(13$ $\mathrm{mm})$ and $H$. indicus $(12 \mathrm{~mm})$ were moderate at a highest concentration, whereas the activity of last three plants was found in all concentrations.

The zone of inhibition of methanol extract of A. macrorrhizos and $H$. indicus (root) was $9.1 \mathrm{~mm}$ and $8.5 \mathrm{~mm}$ against Salmonella, whereas it was $7.5 \mathrm{~mm}$ and $9 \mathrm{~mm}$ against $E$. coli (Farrukh et al., 2008; Ratha et al., 2012). Previous data described the zone of inhibition of J. curcas (latex) methanol extract was $12.3 \mathrm{~mm}$ and $15 \mathrm{~mm}$ at $100 \mathrm{mg} / \mathrm{ml}$ against E. coli and Salmonella and did not fiund any activity of L. lavandulifolia (leaf) against both the microbes (Suhaili et al., 2011; Murugan, Mishra and Paul, 2018). A previous study demonstrates the methanolic extract of $A$. racemosus (root) has high antibacterial activity against E. coli and Salmonella, and B. diffusa did not show any activity against $E$. coli and Salmonella (Umamaheswari, Nuni and Shreevidya, 2010). Methanol extract of $C$. roseus leaf showed antibacterial activity against E. coli and Salmonella that was about $10 \mathrm{~mm}$ and $6 \mathrm{~mm}$, respectively. The root extract showed highest activity, which was 10 $\mathrm{mm}$ and $24 \mathrm{~mm}$ (Raza et al., 2009). 


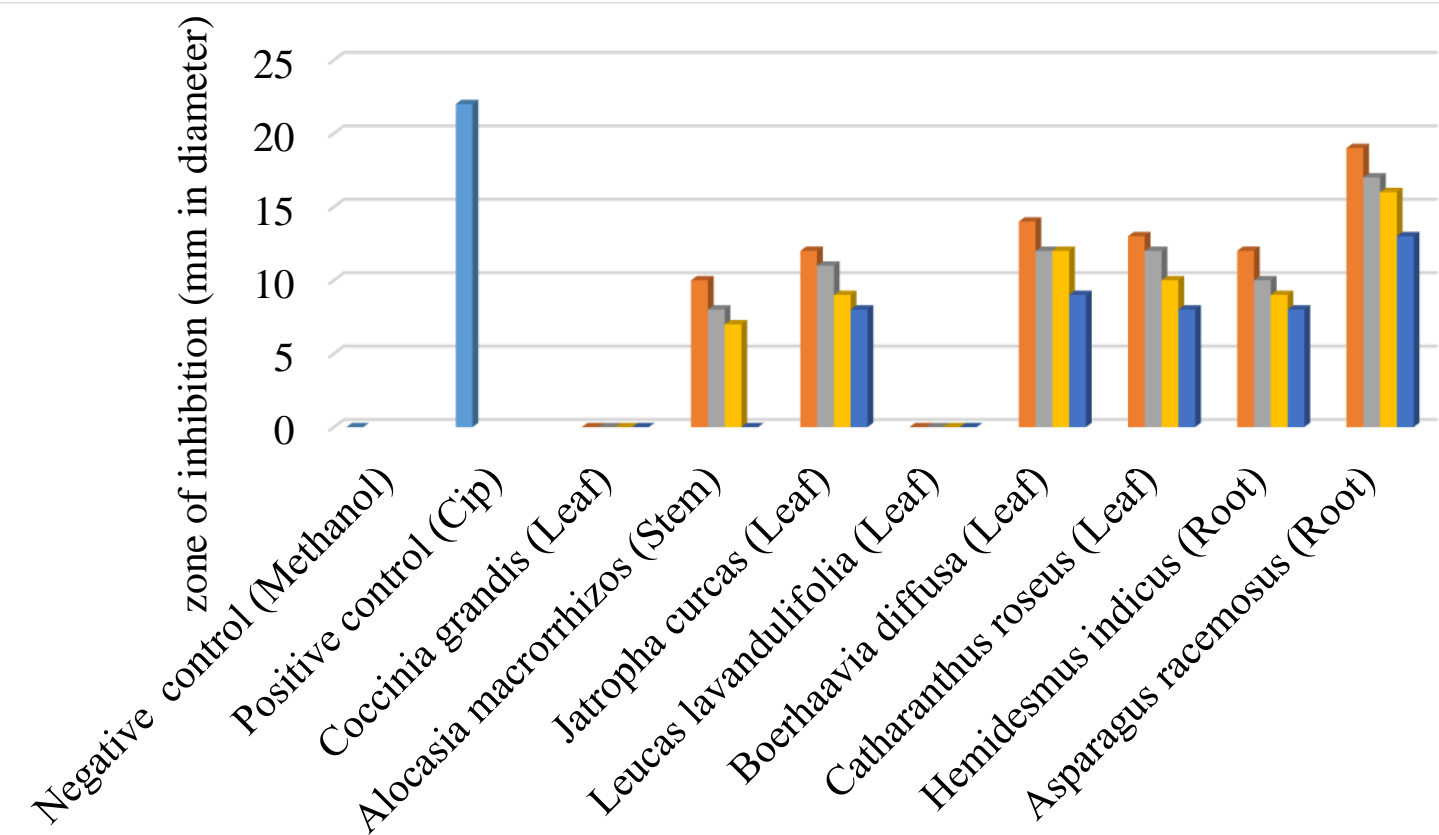

Name of the plants

$\square$ Control $\square 100 \mathrm{mg} / \mathrm{ml} \quad \square 50 \mathrm{mg} / \mathrm{ml} \square 25 \mathrm{mg} / \mathrm{ml} \quad \square 12.5 \mathrm{mg} / \mathrm{ml}$

Figure 7: Antibacterial activity of methanol extracts against Salmonella spp. [Cip = Ciprofloxacin]

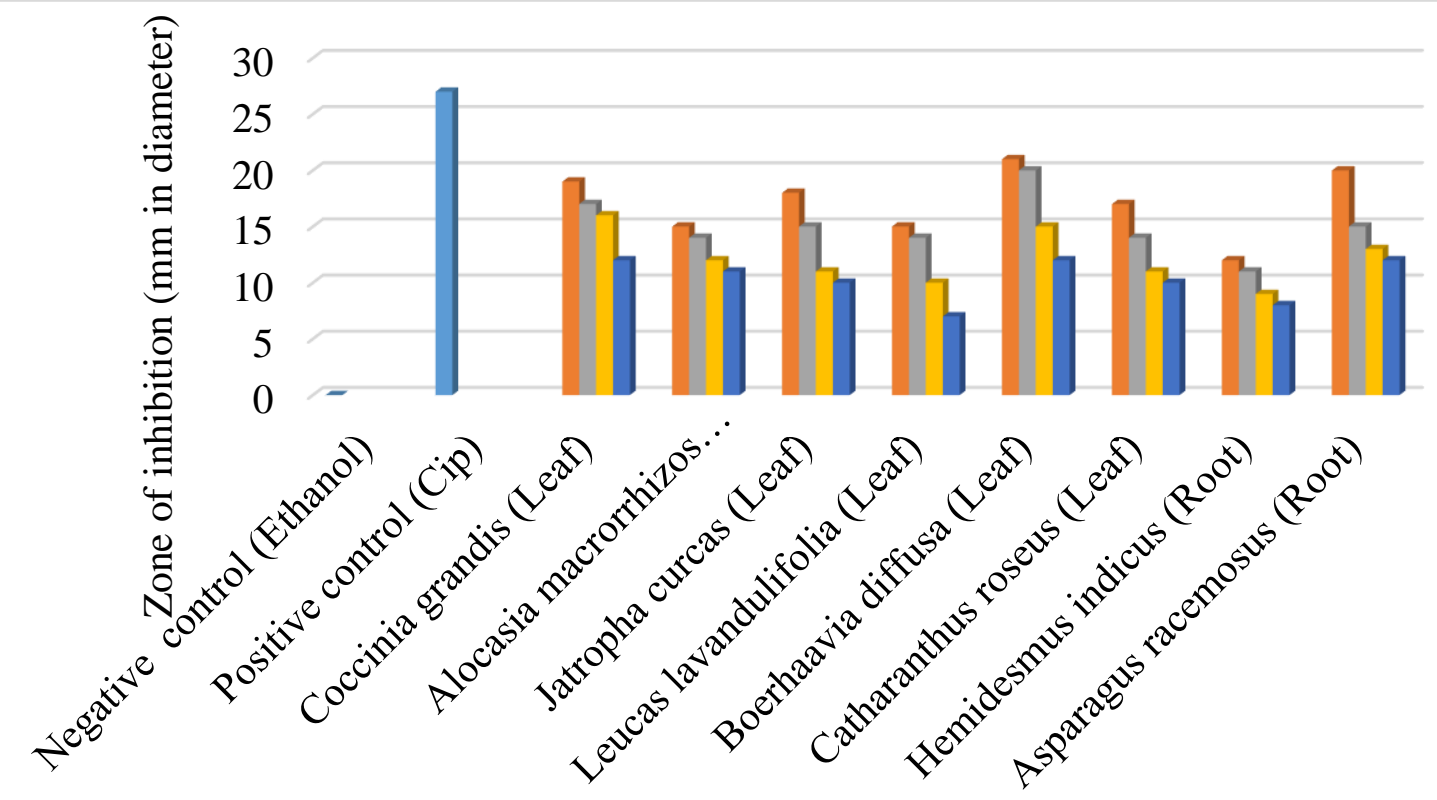

Name of the plants

$\square$ Control $\square 100 \mathrm{mg} / \mathrm{ml} \quad \square 0 \mathrm{mg} / \mathrm{ml} \square 25 \mathrm{mg} / \mathrm{ml} \quad \square 12.5 \mathrm{mg} / \mathrm{ml}$

Figure 8: Antibacterial activity of ethanol extracts against E. coli [Cip = Ciprofloxacin] 
Antibacterial Activity of Ethanol Extracts against E. coli and Salmonella spp.

The activity of ethanolic extract of eight plants in all concentration was recorded against $E$. coli. The ethanolic extract of $B$. diffusa expressed maximum zone of inhibition (21, 20, 15, 12 and 10 $\mathrm{mm})$ in all concentration against $E$. coli. The activity of $A$. racemosus $(20,15,13,12$ and $9 \mathrm{~mm})$ was similar to that of $B$. diffusa. The ethanolic C. roseus $(17 \mathrm{~mm}), J$. curcas $(18 \mathrm{~mm}), C$. grandis $(19 \mathrm{~mm})$ and $H$. indicus $(12 \mathrm{~mm})$ exhibited moderate activity at maximum concentration against E. coli, whereas the activity of $H$. indicus and $L$. lavandulifolia plants extracts was same $(15 \mathrm{~mm})$ at highest concentration.

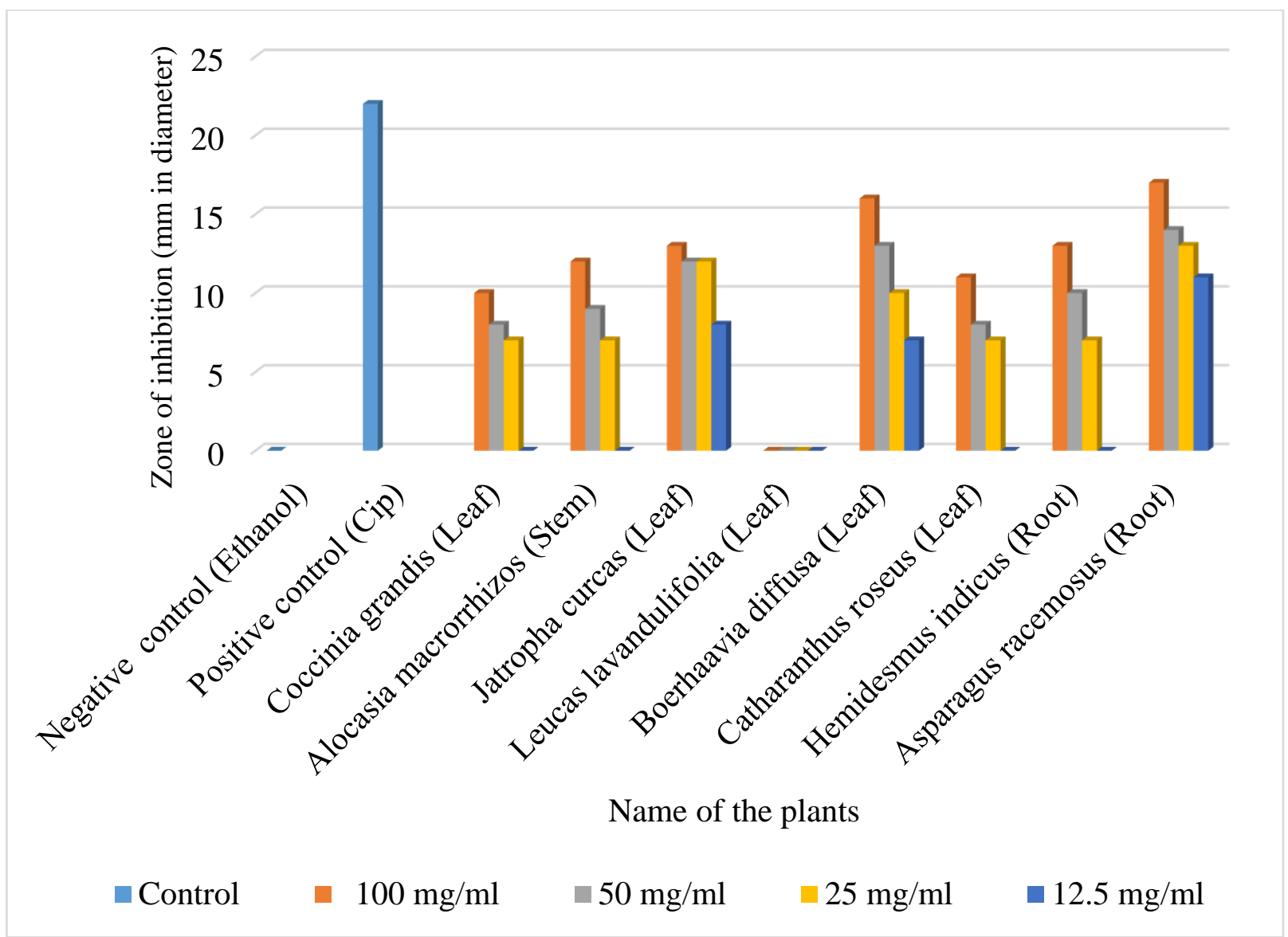

Figure 9: Antibacterial activity of ethanol extracts against Salmonella spp. [Cip = Ciprofloxacin]

Ethanolic extract of $A$. racemosus showed maximum activity $(17,14,13,11$, and $9 \mathrm{~mm})$ in all concentrations (100, 50, 25, 12.5 and $6.25 \mathrm{mg} / \mathrm{ml})$, and L. lavandulifolia did not show any activity against Salmonella. The highest concentration of J. curcas, B. diffusa, C. grandis, A. macrorrhizos, $C$. roseus and $H$. indicus showed 13,16,10,12,11 and $13 \mathrm{~mm}$ zone of inhibition, while last four of these plants did not show any activity against Salmonella in lowest two concentrations (12.5 and $6.25 \mathrm{mg} / \mathrm{ml})$.

The zone of inhibition of ethanol extract of $C$. grandis (stem) was $6.6 \mathrm{~mm}$ against Salmonella and $6 \mathrm{~mm}$ against $E$. coli as showed in the earlier study (Farrukh et al., 2008). The data of the past study demonstrated that ethanol extract of $B$. diffusa leaves showed more activity against a Gram- 
negative bacterium and strongly supports the high antibacterial activity of $A$. racemosus against $E$. coli and Salmonella (Umamaheswari, Nuni and Shreevidya, 2010). Earlier experiments demonstrated that ethanol extract of $H$. indicus (root) expressed their activity against $E$. coli and Salmonella were $11 \mathrm{~mm}$ and $8.5 \mathrm{~mm}$, respectively (Ratha et al., 2012). The previous study supports the finding that ethanol extract of $A$. racemosus (root) has similar activity against those microbes (Samy, Ignacimuthu and Sen, 1998).

Antibacterial Activity of Acetone Extracts against E. coli and Salmonella spp.

Acetone extract of $L$. lavandulifolia $(16,15,13,13$ and $12 \mathrm{~mm})$ showed maximum activity in all concentrations $(100,50,25,12.5,6.25 \mathrm{mg} / \mathrm{ml})$ against $E$. coli, whereas the activity of $C$. grandis, A. macrorrhizos, B. diffusa and $H$. indicus plants did not show the activity in lowest two concentrations (12.5 and $6.25 \mathrm{mg} / \mathrm{ml})$. The zone of inhibition of C. roseus $(15 \mathrm{~mm}), J$. curcas $(14$ $\mathrm{mm})$, A. racemosus $(13 \mathrm{~mm})$, A. macrorrhizos $(10 \mathrm{~mm})$, H. indicus $(9 \mathrm{~mm})$ and C. grandis $(8 \mathrm{~mm})$ gradually decreased compared to the zone of inhibition of L. lavandulifolia in maximum concentration $(100 \mathrm{mg} / \mathrm{ml})$.

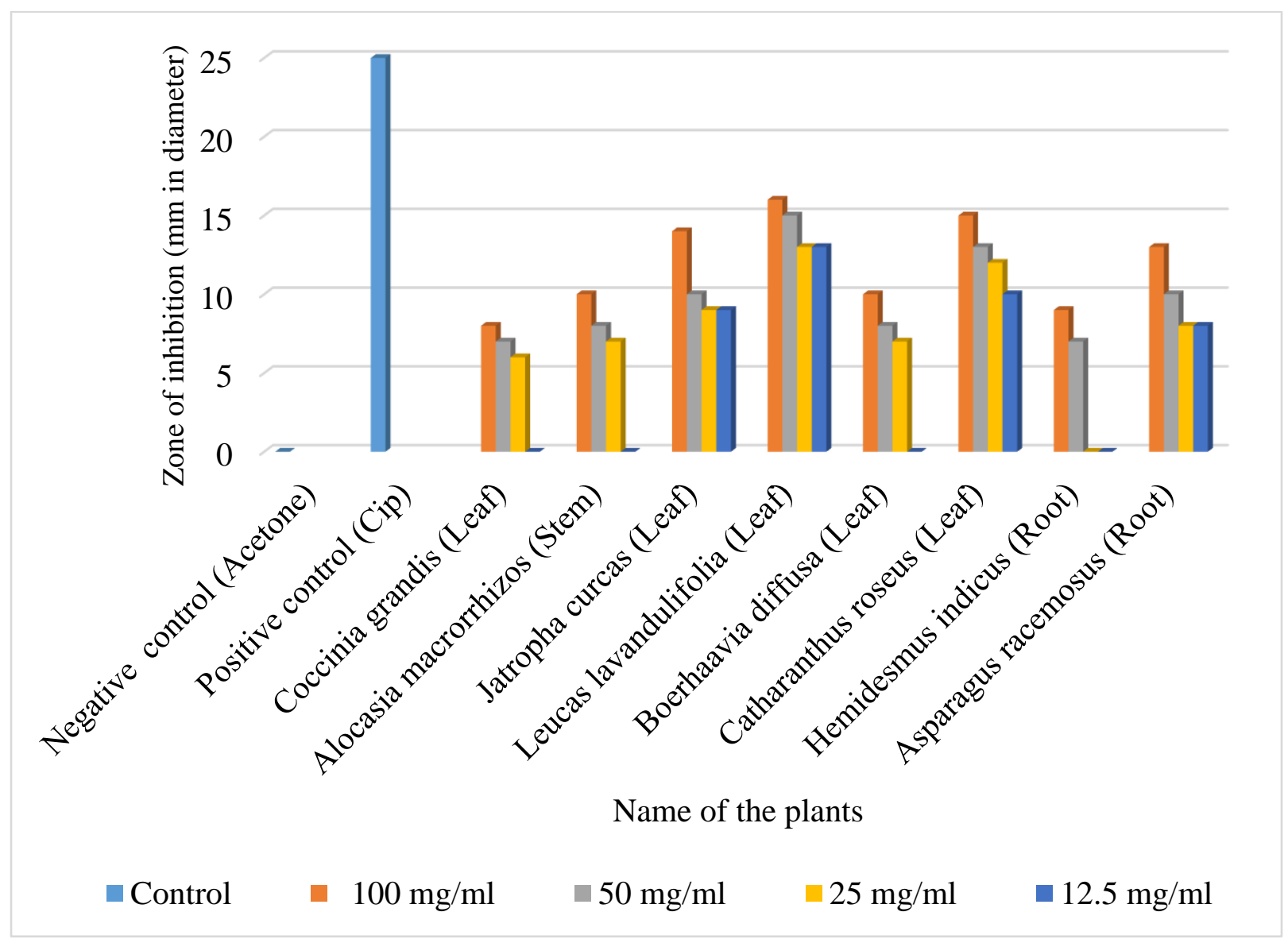

Figure 10: Antibacterial activity of acetone extracts against E. coli [Cip = Ciprofloxacin]

Acetone extract of A. racemosus showed maximum activity $(14,13,10$ and $7 \mathrm{~mm})$ against Salmonella spp. in the first four concentrations, whereas the lowest concentration of all plants did not show any type of activity. The activity of $J$. curcas $(10 \mathrm{~mm})$ and $C$. roseus $11 \mathrm{~mm}$ ) was 
moderately high and the zone of inhibition of B. diffusa, A. macrorrhizos and $H$. indicus showed comparatively small $(8 \mathrm{~mm})$ zone of inhibition against Salmonella at $100 \mathrm{mg} / \mathrm{ml}$ concentration. Acetonic extract of $C$. grandis and $L$. lavandulifolia did not show any activity in any concentration against Salmonella. In an earlier study, it was found that A. racemosus (root) showed moderate zone of inhibition against E. coli and Salmonella (Ahmad, Mehmood and Mohammad, 1998).

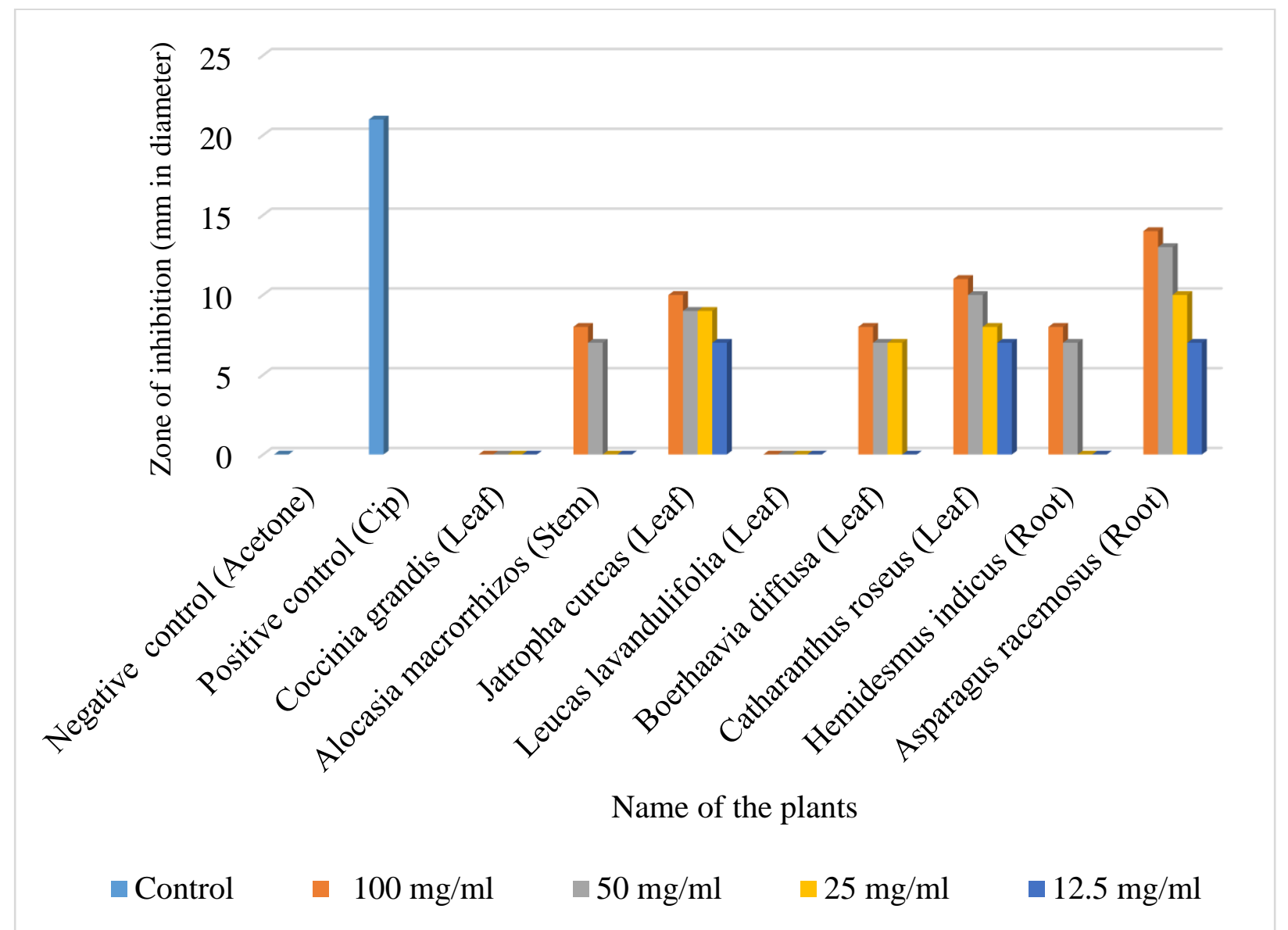

Figure 11: Antibacterial activity of acetone extracts against Salmonella spp. [Cip = Ciprofloxacin]

\section{Conclusion}

Antibiotic resistance has limited the use of antibiotics against infectious microbes. Plant extract which contains phytochemical or secondary metabolites like alkaloids, flavonoids etc. can play an essential role that can block the activity of resistant microbes. The present study showed that the tested eight medicinal plants in the form of aqueous and organic solvent extracts at different concentrations have a positive effect against multi-drug resistant E. coli and Salmonella spp. Thus, it can be concluded that these eight medicinal plants (i.e., Coccinia grandis, Alocasia macrorrhizos, Jatropha curcas, Leucas lavandulifolia, Boerhaavia diffusa, Catharanthus roseus, Hemidesmus indicus, Asparagus racemosus) can be used as a supportive therapy along with the standard antibiotics to treat infectious diseases in broiler chickens. 


\section{References}

Adesiyun, A., Offiah, N., Seepersadsingh, N., Rodrigo, S., Lashley, V. and Musai, L., (2007). Antimicrobial resistance of Salmonella spp. and Escherichia coli isolated from table eggs. Food Control, 18(4): 306-311. Doi: https://doi.org/10.1016/j.foodcont.2005.10.013

Agrawal, A., Srivastava, S., Srivastava, J.N. and Srivastava, M.M. (2004). Inhibitory effect of the plant Boerhavia diffusa 1. against the dermatophytic fungus Microsporum fulvum. Journal of Environmental Biology, 25(3): 307-311.

Ahmad, I. and Beg, A.Z. (2001). Antimicrobial and phytochemical studies on 45 Indian medicinal plants against multi-drug resistant human pathogens. Journal of Ethnopharmacology, 74(2): 113-123. Doi: http://doi.org/10.1016/s0378-8741(00)00335-4

Ahmad, I., Mehmood, Z. and Mohammad, F. (1998). Screening of some Indian medicinal plants for their antimicrobial properties. Journal of Ethnopharmacology, 62(2): 183-193.

Akhter, F., Hashim, A., Khan, M.S., Ahmad, S., Iqbal, D., Srivastava, A.K. and Siddiqui, M.H., (2013). Antioxidant, $\alpha$-amylase inhibitory and oxidative DNA damage protective property of Boerhaavia diffusa (Linn.) root. South African Journal of Botany, 88: 265-272. Doi: https://doi.org/10.1016/j.sajb.2013.06.024

Aladesanmi, A.J., Iwalewa, E.O., Adebajo, A.C., Akinkunmi, E.O., Taiwo, B.J., Olorunmola, F.O. and Lamikanra, A. (2007). Antimicrobial and antioxidant activities of some Nigerian medicinal plants. African Journal of Traditional, Complementary and Alternative Medicines, 4(2): 173-184.

Ansari, A.R.M.I.H., Rahman, M.M., Islam, M.Z., Das, B.C., Habib, A., Belal, S.M.S.H. and Islam, K. (2014). Prevalence and antimicrobial resistance profile of Escherichia coli and Salmonella isolated from diarrheic calves. Journal of Animal Health and Production, 2(1): 12-15.

Banik, S., Ibrahim, M., Amin, M.N., Moghal, M.M.R., Majumder, M.S., Alam, M.K., Anonna, S.N. and Rashed, M.S.U., (2014). Determination of biological properties of Alocasia Macrorrhizos: A medicinal plant. World Journal of Pharmaceutical Research, 3(9): 193210.

Bashir, S., Erum, A. and Kausar, R., (2012). Antimicrobial activity of some ethno-medicinal plants used in Pakistan. Research in Pharmacy, 2(1): 42-45.

Bullock N.O., Aslanzadeh J. (2013) Biochemical Profile-Based Microbial Identification Systems. In: Tang YW., Stratton C. (eds) Advanced Techniques in Diagnostic Microbiology. Springer, Boston, MA. Doi: https://doi.org/10.1007/978-1-4614-3970-7_

Carvalho, I.T. and Santos, L., (2016). Antibiotics in the aquatic environments: a review of the European scenario. Environment International,94: 736-757. Doi: https://doi.org/10.1016/j.envint.2016.06.025

Chattopadhyay, M.K., (2014). Use of antibiotics as feed additives: a burning question. Frontiers in microbiology, 5: 334. Doi: https://doi.org/10.3389/fmicb.2014.00334

Chetri, S., Das, B.J., Bhowmik, D., Chanda, D.D., Chakravarty, A. and Bhattacharjee, A., (2020). Transcriptional response of mar, sox and rob regulon against concentration gradient carbapenem stress within Escherichia coli isolated from hospital acquired infection. BMC research notes, 13(1): 1-7.

Cioch, M., Satora, P.A.W.E.Ł., Skotniczny, M., Semik-Szczurak, D. and Tarko, T., (2017). Characterisation of antimicrobial properties of extracts of selected medicinal plants. Polish journal of microbiology, 66(4): 463-472. 
Dada, E.O., Ekundayo, F.O. and Makanjuola, O.O., (2014). Antibacterial activities of Jatropha curcas (LINN) on coliforms isolated from surface waters in Akure, Nigeria. International Journal of Biomedical Science: IJBS, 10(1): 25.

Das, S. and Devaraj, S.N., (2006). Glycosides derived from Hemidesmus indicus R. Br. root inhibit adherence of Salmonella typhimurium to host cells: receptor mimicry. Phytotherapy Research: An International Journal Devoted to Pharmacological and Toxicological Evaluation of Natural Product Derivatives, 20(9): 784-793. Doi: https://doi.org/10.1002/ptr.1963

de Kraker, M.E., Stewardson, A.J. and Harbarth, S., (2016). Will 10 million people die a year due to antimicrobial resistance by 2050?. PLoS medicine, 13(11): 1002184. Doi: https://doi.org/10.1371/journal.pmed.1002184

Dibner, J.J. and Richards, J.D., (2005). Antibiotic growth promoters in agriculture: history and mode of action. Poultry science, 84(4): 634-643. Doi: https://doi.org/10.1093/ps/84.4.634

Emami, N.K., Samie, A., Rahmani, H.R. and Ruiz-Feria, C.A., (2012). The effect of peppermint essential oil and fructooligosaccharides, as alternatives to virginiamycin, on growth performance, digestibility, gut morphology and immune response of male broilers. Animal Feed Science and Technology, 175(1-2): 57-64. Doi: https://doi.org/10.1016/j.anifeedsci.2012.04.001

Evans, D.A., Rajasekharan, S. and Subramoniam, A., (2004). Enhancement in the absorption of water and electrolytes from rat intestine by Hemidesmus indicus R. Br. root (water extract). Phytotherapy Research: An International Journal Devoted to Pharmacological and Toxicological Evaluation of Natural Product Derivatives, 18(7): 511-515. Doi: https://doi.org/10.1002/ptr.1402

Fadare, J.O., Ogunleye, O., Iliyasu, G., Adeoti, A., Schellack, N., Engler, D., Massele, A. and Godman, B., (2019). Status of antimicrobial stewardship programmes in Nigerian tertiary healthcare facilities: findings and implications. Journal of global antimicrobial resistance, 17: 132-136. Doi: https://doi.org/10.1016/j.jgar.2018.11.025

Forgetta, V., Rempel, H., Malouin, F., Vaillancourt Jr, R., Topp, E., Dewar, K. and Diarra, M.S., (2012). Pathogenic and multidrug-resistant Escherichia fergusonii from broiler chicken. Poultry science, 91(2): 512-525. Doi: https://doi.org/10.3382/ps.2011-01738

Furtula, V., Farrell, E.G., Diarrassouba, F., Rempel, H., Pritchard, J. and Diarra, M.S., (2010). Veterinary pharmaceuticals and antibiotic resistance of Escherichia coli isolates in poultry litter from commercial farms and controlled feeding trials. Poultry science, 89(1): 180-188. Doi: https://doi.org/10.3382/ps.2009-00198

Goyal, R.K., Singh, J. and Lal, H., (2003). Asparagus racemosus-an update. Indian journal of medical sciences, 57(9): 408-414.

Harborne, J.B., Baxter, H. and Webster, F.X., (1994). Phytochemical dictionary: a handbook of bioactive compounds from plants. Journal of Chemical Ecology, 20(3): 815-818.

Harvey, A.L., Edrada-Ebel, R. and Quinn, R.J., (2015). The re-emergence of natural products for drug discovery in the genomics era. Nature reviews drug discovery, 14(2): 111-129.

Hasan, T. and Sultana, M., (2018). Antidiabetic potency of Bangladeshi medicinal plants. $J$ Ayurvedic Herb Med, 4(1): 35-42.

Hassan, H.M.A., Mohamed, M.A., Youssef, A.W. and Hassan, E.R., (2010). Effect of using organic acids to substitute antibiotic growth promoters on performance and intestinal microflora of broilers. Asian-Australasian Journal of Animal Sciences, 23(10): 1348-1353. Doi: https://doi.org/10.5713/ajas.2010.10085 
Hossain, M., Hoda, N., Hossen, M.J., Hasan, M.M., Rahman, S.M.E. and Kabir, S.L., (2015). Assessment of bacterial load of poultry meat used at dining hall of Bangladesh Agricultural University campus. Asian Journal of Medical and Biological Research, 1(1): 9-16. Doi: https://doi.org/10.3329/ajmbr.v1i1.25492

Kainsa, S., Kumar, P. and Rani, P., (2012). Medicinal plants of Asian origin having anticancer potential: short review. Asian J Biomed Pharm Sci, 2(10): 1-11.

Kavitha, B.T., Ramachandra, Y.L., Padmalatha Rai, S., Sudeep, H.V. and Krishana, S., (2010). A TIBACTERIAL ACTIVITY OF THE ROOT EXTRACTS OF HEMIDESMUS I DICUS, 2: 711-716.

Kunwar, R.M., Uprety, Y., Burlakoti, C., Chowdhary, C.L. and Bussmann, R.W., (2009). Indigenous use and ethnopharmacology of medicinal plants in far-west Nepal. Ethnobotany research and applications, 7: 005-028.

Kumar, B., Rani, R., Das, S. and Das, S., (2012). Phytoconstituents and therapeutic potential of Thuja occidentalis. Research Journal of Pharmaceutical, Biological and Chemical Sciences, 3(2): 354-362.

Lee, K.W., Hong, Y.H., Lee, S.H., Jang, S.I., Park, M.S., Bautista, D.A., Ritter, G.D., Jeong, W., Jeoung, H.Y., An, D.J. and Lillehoj, E.P., (2012). Effects of anticoccidial and antibiotic growth promoter programs on broiler performance and immune status. Research in veterinary science, 93(2): 721-728. Doi: https://doi.org/10.1016/j.rvsc.2012.01.001

Lee, W., Li, Z.H., Vakulenko, S. and Mobashery, S., (2000). A light-inactivated antibiotic. Journal of medicinal chemistry, 43(1): 128-132.

Makhija, I.K., Chandrashekar, K.S., Richard, L. and Jaykumar, B., (2011). Phytochemical and Pharmacological profile of Leucas lavandulaefolia: A review. Research Journal of Medicinal Plants, 5(5): 500-507. Doi: 3923/rjmp.2011.500.507.

Mandal, P., Misra, T.K. and Singh, I.D., (2010). Antioxidant activity in the extracts of two edible aroids. Indian journal of pharmaceutical sciences, 72(1): $105 . \quad$ Doi: https://dx.doi.org/10.4103\%2F0250-474X.62242

Mandal, S.C., CK, A.K., Lakshmi, S.M., Sinha, S., Murugesan, T., Saha, B.P. and Pal, M., (2000). Antitussive effect of Asparagus racemosus root against sulfur dioxide-induced cough in mice. Fitoterapia, 71(6): 686-689. Doi: https://doi.org/10.1016/S0367-326X(00)00151-9

Manjunath, G.N., Prakash, R. and Vamseedhar Annam, K.S., (2011). Changing trends in the spectrum of antimicrobial drug resistance pattern of uropathogens isolated from hospitals and community patients with urinary tract infections in Tumkur and Bangalore. Int J Biol Med Res., 2(2): 504-507.

Miller, M.J., MacNaughton, W.K., Zhang, X.J., Thompson, J.H., Charbonnet, R.M., Bobrowski, P., Lao, J., Trentacosti, A.M. and Sandoval, M., (2000). Treatment of gastric ulcers and diarrhea with the Amazonian herbal medicine sangre de grado. American Journal of Physiology-Gastrointestinal and Liver Physiology, 279(1): 192-G200. Doi: https://doi.org/10.1152/ajpgi.2000.279.1.G192

Morton, J.F., (1980). Caribbean and Latin American folk medicine and its influence in the United States. Quarterly Journal of Crude Drug Research,18(2): 57-75. Doi: https://doi.org/10.3109/13880208009065179

Muhammad, L.R., Muhammad, N., Tanveer, A. and Baqir, S.N., (2009). Antimicrobial activity of different extracts of Catharanthas roseus. Clin. Exp. Med. J, 3: 81-85.

Mulatu, G., Beyene, G. and Zeynudin, A., (2014). Prevalence of Shigella, Salmonella and Cmpylobacter species and their susceptibility patters among under five children with diarrhea in Hawassa town, South Ethiopia. Ethiopian journal of health sciences, 24(2): 101. 
Murugan, N.B., Mishra, B.K. and Paul, B., (2018). Antioxidant and antibacterial evaluation of medicinal plants used in the starter culture (Wanti) of fermented rice beverage in West Garo hills, Meghalaya. J. Pharmacogn. Phytochem, 7: 1669-1674.

Nesa, M.K., Khan, M.S.R. and Alam, M., (2011). Isolation, identification and characterization of salmonella serovars from diarrhoeic stool samples of human. Bangladesh Journal of Veterinary Medicine, 9(1): 85-93. Doi: https://doi.org/10.3329/bjvm.v9i1.11218

Olukoya, D.K., Idika, N. and Odugbemi, T., (1993). Antibacterial activity of some medicinal plants from Nigeria. Journal of ethnopharmacology,39(1): 69-72. Doi: https://doi.org/10.1016/0378-8741(93)90051-6

Quinlan, M.B., Quinlan, R.J. and Nolan, J.M., (2002). Ethnophysiology and herbal treatments of intestinal worms in Dominica, West Indies. Journal of Ethnopharmacology, 80(1): 75-83. Doi: https://doi.org/10.1016/S0378-8741(02)00002-8.

Rahman, M.M., Ahmad, S.H., Mohamed, M.T.M. and Ab Rahman, M.Z., (2014). Antimicrobial compounds from leaf extracts of Jatropha curcas, Psidium guajava, and Andrographis paniculata. The Scientific World Journal, 2014: 1-8. Doi: https://doi.org/10.1155/2014/635240

Rampadarath, S., Puchooa, D. and Jeewon, R., (2016). Jatropha curcas L: Phytochemical, antimicrobial and larvicidal properties. Asian Pacific Journal of Tropical Biomedicine, 6(10): 858-865. Doi: https://doi.org/10.1016/j.apjtb.2016.01.019

Ratha, M., Subha, K., Senthilkumar, G. and Panneerselvam, A., (2012). Screening of phytochemical and antibacterial activity of Hemidesmus indicus (L.) and Vetiveria zizanoides (L.). Eur. J. Exp. Biol, 2(2): 363-368.

Raza, M.L., Nasir, M., Abbas, T. and Naqvi, B.S., (2009). Antibacterial activity of different extracts from the Catharanthus roseus. Clinical and Experimental Medical Journal, 3(1): 81-85. Doi: https://doi.org/10.1556/CEMED.3.2009.1.7

Ronquillo, M.G. and Hernandez, J.C.A., (2017). Antibiotic and synthetic growth promoters in animal diets: review of impact and analytical methods. Food Control, 72: 255-267. Doi: https://doi.org/10.1016/j.foodcont.2016.03.001

Rossiter, S.E., Fletcher, M.H. and Wuest, W.M., (2017). Natural products as platforms to overcome antibiotic resistance. Chemical reviews, 117(19): 12415-12474.

Saha, S.K., Baqui, A.H., Darmstadt, G.L., Ruhulamin, M., Hanif, M., El Arifeen, S., Oishi, K., Santosham, M., Nagatake, T. and Black, R.E., (2005). Invasive Haemophilus influenzae type $\mathrm{b}$ diseases in Bangladesh, with increased resistance to antibiotics. The Journal of pediatrics, 146(2): 227-233. Doi: https://doi.org/10.1016/j.jpeds.2004.09.007

Sahu, A., Damiki, L., Nilanjan, G. and Dubey, S., (2008). Phytopharmacological review of Boerhaavia diffusa Linn.(Punarnava). Pharmacognosy Reviews, 2(4): 14.

Sakharkar, P. and Chauhan, B., (2017). Antibacterial, antioxidant and cell proliferative properties of Coccinia grandis fruits. Avicenna journal of Phytomedicine, 7(4): 295.

Samy, R.P., Ignacimuthu, S. and Sen, A., (1998). Screening of 34 Indian medicinal plants for antibacterial properties. Journal of ethnopharmacology,62(2): 173-181. Doi: https://doi.org/10.1016/S0378-8741(98)00057-9

Schroeder, M., Brooks, B.D. and Brooks, A.E., (2017). The complex relationship between virulence and antibiotic resistance. Genes, 8(1): $39 . \quad$ Doi: https://doi.org/10.3390/genes8010039

Singh, P., Karimi, A., Devendra, K., Waldroup, P.W., Cho, K.K. and Kwon, Y.M., (2013). Influence of penicillin on microbial diversity of the cecal microbiota in broiler chickens. Poultry science, 92(1): 272-276. Doi: https://doi.org/10.3382/ps.2012-02603 
Sinha, S.N. and Biswas, M., (2011). Effect of extracts from Asparagus racemosus willd root against pathogenic bacteria. International journal of applied biology and pharmaceutical technology, 2(3): 312-314.

Sivaraj, A., Jenifa, B.P., Kavitha, M., Inbasekar, P., Senthilkumar, B. and Panneerselvam, A., (2011). Antibacterial activity of Coccinia grandis leaf extract on selective bacterial strains. Journal of Applied Pharmaceutical Science, 1(7): 12.

Srivastava, V., Mubeen, S., Semwal, B.C. and Misra, V., (2012). Biological activities of Alocasia macrorrhiza: A review. Sciences, 2: 01.

Suhaili, Z., Yeo, C.C., Yasin, H.N., Badaludin, N.A. and Zakaria, Z.A., (2011). Antibacterial profile of Jatropha curcas latex extracts against selected human pathogenic bacteria. African Journal of Microbiology Research, 5(29): 5147-5154. Doi: https://doi.org/10.5897/AJMR11.663

Tambekar, D.H., Khante, B.S., Chandak, B.R., Titare, A.S., Boralkar, S.S. and Aghadte, S.N., (2009). Screening of antibacterial potentials of some medicinal plants from Melghat forest in India. African Journal of Traditional, Complementary and Alternative Medicines, 6(3): 228 $-232$.

Thabit, A.K., Crandon, J.L. and Nicolau, D.P., (2015). Antimicrobial resistance: impact on clinical and economic outcomes and the need for new antimicrobials. Expert Opinion on Pharmacotherapy, 16(2): 159-177. Doi: https://doi.org/10.1517/14656566.2015.993381

Torok, V.A., Allison, G.E., Percy, N.J., Ophel-Keller, K. and Hughes, R.J., (2011). Influence of antimicrobial feed additives on broiler commensal posthatch gut microbiota development and performance. Applied and environmental microbiology, 77(10): 3380-3390. Doi: 10.1128/AEM.02300-10.

Wilasrusmee, C., Kittur, S., Shah, G., Siddiqui, J., Bruch, D., Wilasrusmee, S. and Kittur, D.S., (2002). Immunostimulatory effect of Silybum Marianum (milk thistle) extract. Medical Science Monitor, 8(11): BR439-BR443.

Wright, G.D., (2017). Opportunities for natural products in 21 st century antibiotic discovery. Natural product reports, 34(7): https://doi.org/10.1039/C7NP00019G

Zrostllkova, J., Hajšlová, J., Poustka, J. and Begany, P., (2002). Alternative calibration approaches to compensate the effect of co-extracted matrix components in liquid chromatographyelectrospray ionisation tandem mass spectrometry analysis of pesticide residues in plant materials. Journal of Chromatography,973(1-2): $\quad$ 13-26. $\quad$ Doi: https://doi.org/10.1016/S0021-9673(02)01196-2. 